\title{
Anaerobic Wastewater Treatments: Prediction of Retention Time on RT/RW Plant
}

\author{
Dessy Agustina Sari ${ }^{*}$, Sukanta ${ }^{2}$, and Azafilmi Hakiim ${ }^{3}$
}

\begin{abstract}
Wastewater treatment gave major problem in higher of chemical oxygen demand that backgrounded by amount and type of PT RT/RW products. The waste was polymer, mixture of nitrogen, mixture of phosphate, and oil. This factory used active sludge and microorganism (anaerobic condition). Research result showed that $\mathrm{pH}$ ranged 4,94 until 8,02. This data gave a decreasing sharply in acidic condition. The thing could be caused acetogenic phase in area pond anaerobic. The phenomenon might be recited because possibility of biologist living this waste did not take place as well and or could give deathly affect to the anaerobic bacteria. Customary $\mathrm{pH}$ for the bacteria was $6,8-7,4$. Temperature data reached $28-33^{\circ} \mathrm{C}$ so their activities were good. Then, efficiency of anaerobic wastewater treatment was 62,95 to $66,06 \%$. The data indicated that the research was not accordance with SOP companies. Inlet concentration of chemical oxygen demand had variation and gave unbalancing affect to digestive bacteria load. Estimation to get valid COD was 11-14 days. The duration was required by the microorganism to digest the matter organic perfectly to be methane and carbon dioxide gas.
\end{abstract}

Keywords-anaerobic process, $\mathrm{COD}, \mathrm{pH}$, retention time, temperature

\section{INTRODUCTION}

$\mathbf{N}$ OWADAYS,a to-do industry was being one of any development in Indonesia country, especially Karawang regency - West Java.Customer demands were the reason to build many plants and that thing created much effect as the consequence from industry sphere environment Waste that produced had stained the soil. Quality reduction of clean water was to be dilemma for civil resident in surroundings the area. Bumi Pangkal Perjuangan was loaded chemical industry, manufacture, automotive, and others. More than one thousand factories (local and foreign) were present in here. Their location was nearly Citarum stream current where blackened the industry disposal. Waste water contained many chemical substances such as $\mathrm{Fe}$ and $\mathrm{Mn}$ dissolve, $\mathrm{Cr}, \mathrm{Hg}, \mathrm{Cu}$, $\mathrm{Pb}$, and others that to be poison and dangerous so the waste water treatment should be applied. The banishment to river or domain had accomplished standardization which ruled by KEP-51/MENLH/10/1995[1].

Company RT/RW was one of factory that making specialty chemical matters for water treatment, power generation, cooling system, wood and paper industry, metal factory, then process and refinery oil plant. The RT/RW liquid waste was

${ }^{1}$ Department of Electrical Engineering, Faculty of Engineering, Universitas Singaperbangsa Karawang - West Java, Indonesia.

${ }^{2}$ Department of Industrial Engineering, Faculty of Engineering, Universitas Singaperbangsa Karawang - West Java Indonesia

${ }^{3}$ Department of Industrial Engineering, Faculty of Engineering, Universitas Singaperbangsa Karawang - West Java, Indonesia.

*Correspondence to T. Author, email: dessy.agustina8@gmail.com.

Telp.: +6285269218687 managed by itself with four steps assembling that resumed in belong to Figure 1. The composition was polymer, mixture nitrogen, mixture phosphate, and oil. The detail was showed on Table 1 below.

TABLE I

THE LIQUID WASTE PT RT/RW

\begin{tabular}{lc}
\hline \hline \multicolumn{1}{c}{ Source } & $\begin{array}{c}\text { Flowrate, } \\
\mathrm{m}^{3} / \text { day }\end{array}$ \\
\hline Blending wash from plant & 2 \\
Container wash and ex drum & 3 \\
Laboratory and kitchen wash & 1 \\
\hline Total & 6 \\
\hline \hline
\end{tabular}

That waste handling had given many troubles for Waste Water Treatment Unit, higher chemical oxygen demand (COD), temperature, total dissolved solid (TDS), biological oxygen demand (BOD), $\mathrm{pH}$, mixed liquor suspended solid (MLSS), etc. Prefix problem was sumand type products. The company determined the anaerobic waste water treatment system. This method could reduce the treatment volume, enhance stability, destruction pathogens, and producing methane [2], [3]. The COD parameter goal could reach efficiency in the amount of $80-90 \%$.Generally, more than $84 \%$ was a good point for both the COD and BOD [4]. Much organic material became the processing principle background.

Duration of retention time was needed to explore the range of optimally liquid waste treating. This thing was did because its minus gave an unpleasant odor (most important while produced sulfide acid), the activity required more time to accomplish its job before the sample went to the aerobic proceed, contributed in nitrite level enhancing (be existed the advanced handling before the waste was flowed to disposal channel). Longer retention time made almost all of volatile acid to be methane and carbon dioxide gas. Furthermore, limit of acidity degree $(\mathrm{pH})$ for the waste was $6-9$. The distance helpful the water animal plant growth.Number of $28-30^{\circ} \mathrm{C}$ acted as valid temperature for the safe waste.Both of temperature and $\mathrm{pH}$ could affect the performance of reactor.

The score of COD process that measured was 14 - 28 times from the standard quality (maximum $300 \mathrm{mg} \mathrm{O}_{2} / \mathrm{L}$ ). This case study proposed to evaluate the performance of anaerobic waste water treatment (efficiency segment). There was the estimation of retention time to predict the organic substance dissociation perfectly before going into the next step.

\section{WASTE WATER TREATMENT AND SAMPLE TESTING}

The waste passed four ways to reach a good quality before exiled to the circles. The sampling wason the third step (see Figure 1) and the procedure for the thing was explained on Figure 2 this below. 


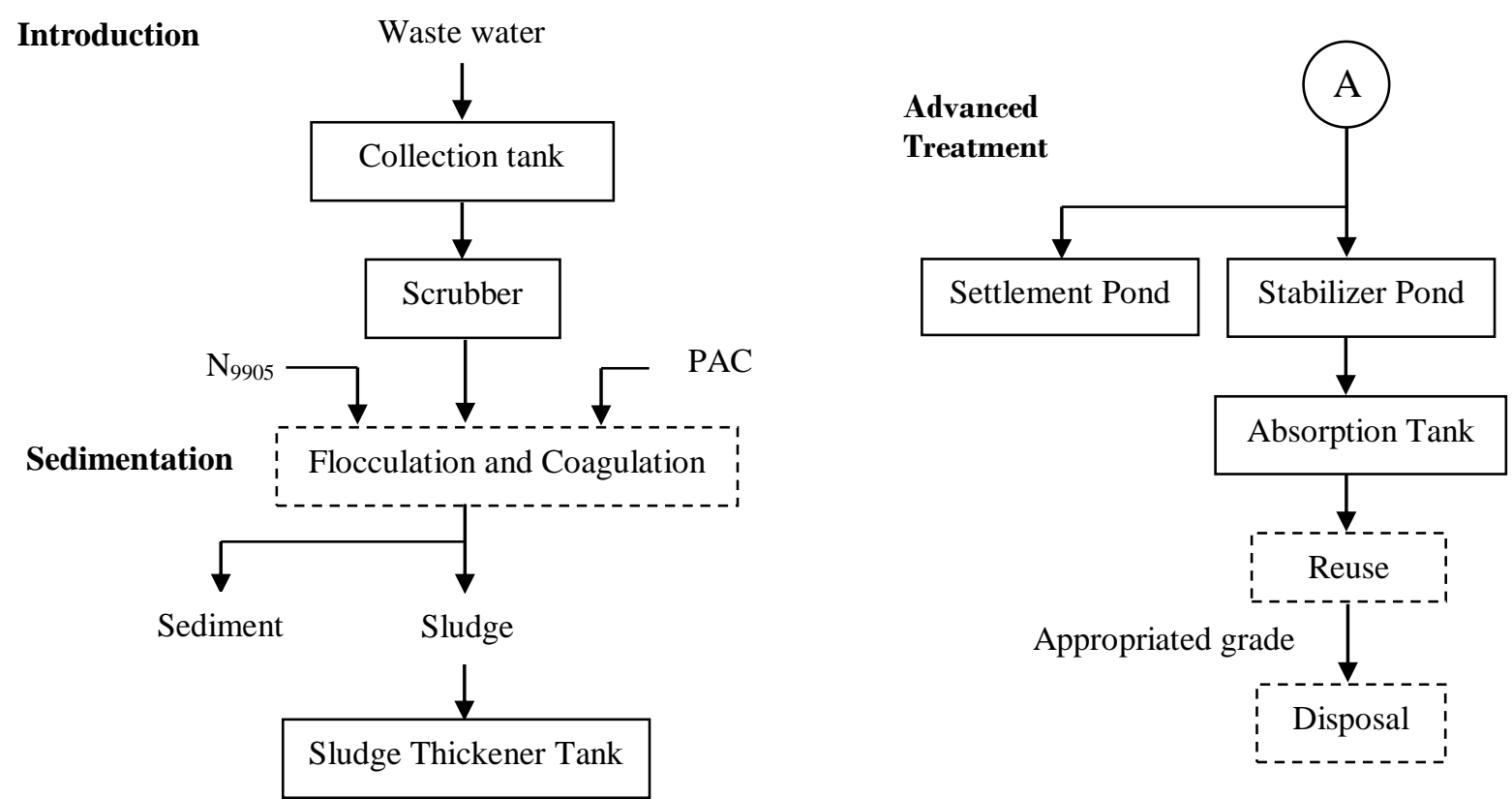

Fig.1. Waste water treatment scheme
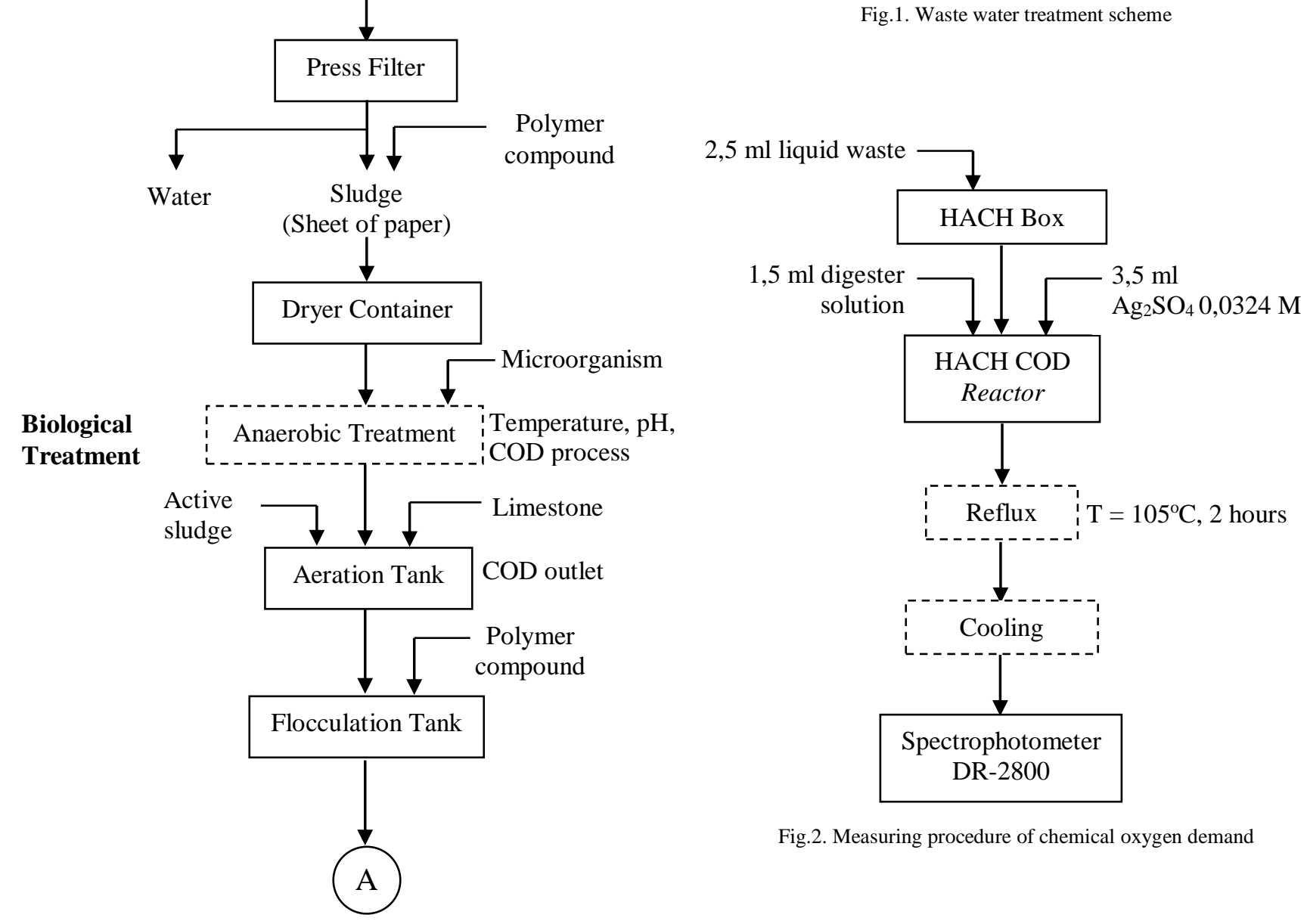

Fig.2. Measuring procedure of chemical oxygen demand 


\section{RESULT AND DISCUSSION}

The liquid waste processing used trial time as along six days to reduce the COD contents. This research made an assumption that the parameter value decreased logarithmically. The experiment data could be seen in Figure 3 . The $\mathrm{pH}$ and temperature gauging in the discharge anaerobic treatment were given in Table 2.

TABLE II

TEMPERATURE AND ACIDITY DEGREE IN THE ANAEROBIC PROCESS

\begin{tabular}{ccc}
\hline \hline Day & $\begin{array}{r}\text { Temperature, } \\
{ }^{\circ} \mathrm{C}\end{array}$ & $\mathrm{pH}$ \\
\hline 1 & 28 & 8,02 \\
2 & 29 & 7,50 \\
3 & 31 & 5,06 \\
4 & 30 & 5,72 \\
5 & 31 & 6,71 \\
6 & 29 & 6,78 \\
\hline \hline
\end{tabular}

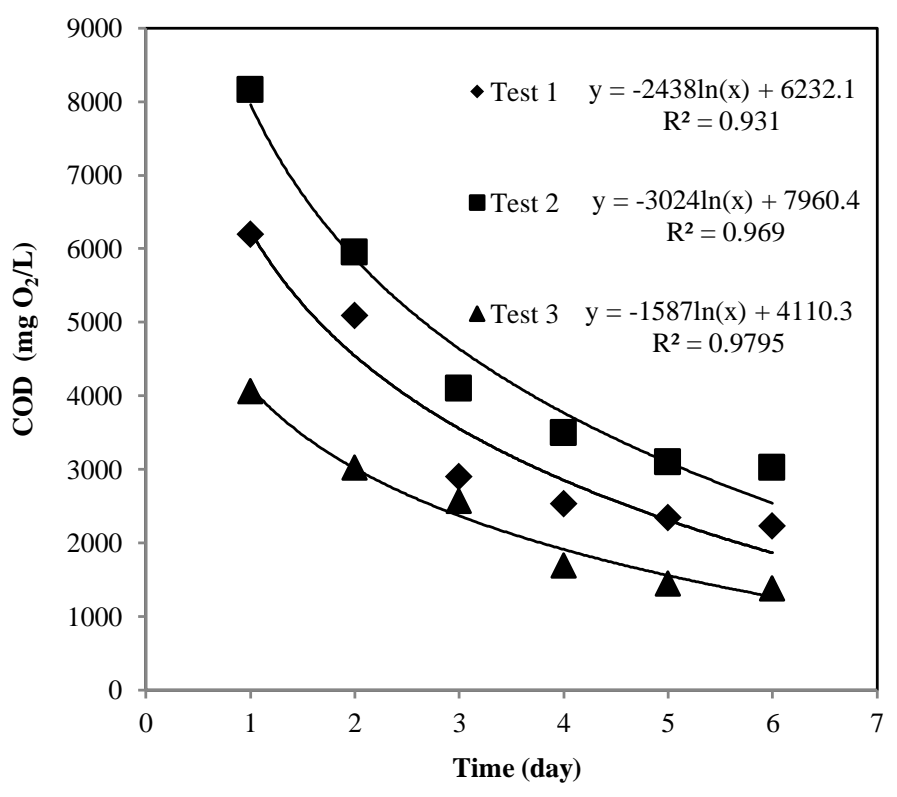

Fig.3. Reduction of waste chemical oxygen demand in six days

The research has been done as three times and Table I was the one of its result. The graph of COD data to time delivered the estimate equation of retention time. The organic matter digestion was well donewhich requiring 11 until 14 days to complete the process. This effort was aimed to get the reasonable COD quality. The first to third experiments had the different final score of COD process $( \pm 6300,8200$, and $4100 \mathrm{mg} \mathrm{O}_{2} / \mathrm{L}$ respectively research) so the same way of treating in anaerobic process also gave a significantly difference on COD outlet data $( \pm 2300,3200$, and $1400 \mathrm{mg}$ $\mathrm{O}_{2} / \mathrm{L}$, consecutively). The COD parameter had efficiency range of $62-66 \%$ as long six days for trial and errorexperiments. The result revealed thatpossibility of organic matter deterioration was overloading. Longer time was needed for methane generation to stabilize[5]. The same statement was in anaerobic digester plant about level of volatile fatty acid [6]. The output also showed that the waste was not compatible to throw away. Thus, reason of low COD removal rate was imbalance in microbial activities, and negative-collapse of the deterioration [7], [8].

Longer retention time could be option through the mathematic calculation. However, company RT/RW could not do the scientific solution because this case had amount of waste and factory product that be variousmade unpredictable load. This incident would be over tank capacity. More than 10 days of retention time gave a risk. Existing of partial sludge stabilization happened in activated sludge process and caused in low efficiency both from a processing and economic aspect.Possible chance that took company RT/RWwas the microorganism quantity improvement to describe organic matter to be methane and carbon dioxide gas. Other idea was the anaerobic step to be staged, and or parallel process (distribution of processing) to get the COD of 150-300 mg $\mathrm{O}_{2} / \mathrm{L}$. That option would be done if the test result on Advanced Treatment was far away from standardization.

This resulted was also supported by review article that giving suggestion to enhance the efficiency of reactor through maintenance optimal of operating conditions [9]. Using a semi-continuous stirring tank could decrease the retention time with waste activated sludge from 32 to 6,4 days on sludge reduction, soluble chemical oxygen demand, and dehydration capability[10].pH achievement gave average value of 6,$63 ; 6,20$; and 6,54 in each repetition experiment. Then, the waste temperature was 29,$67 ; 30,00$; and 29,83 in respectively. Both of testing has been corresponding. Temperature played an important role to support the activity of digestive bacteria on the anaerobic liquid waste treatment. This data indicated that the process that occurring did not disturb their doing in anaerobic tank. However, the lacking would be happen if condition was under $10^{\circ} \mathrm{C}$. On food waste research, discharge of temperature mesophilic was $35-57^{\circ} \mathrm{C}$. This thing could improve reaction rates, higher gas production and also destruction of pathogen [11].

Significant losing was present at the third measuring where the waste became more acidic. This phenomenon could be caused acetogenic phase that taking place on the anaerobic tank. The microorganism needed environment with $\mathrm{pH}$ of 6,8 - 7,4. Less 6 or up 8 point gave an effect that the creature could not work very well. The water $\mathrm{pH}$ that not being neutral produced a difficult in biological treatment, and also this thing could kill the bacteria in the water.

\section{CONCLUSION}

The waste water treatment in company $\mathrm{RT} / \mathrm{RW}$ needed almost 2 weeks for the bacteria to remodel the organic fed in totality before going to the aerobic process. The research also produced $\mathrm{pH}$ and temperature that reaching the disposal quality. Processing development was keep built to reduce COD so the retention time was no more six days. 


\section{REFERENCES}

[1] M. L. H. Menteri Lingkungan Hidup, Lampiran: Keputusan Menteri Lingkungan Hidup Nomor: KEP-51/MENLH/10/1995 tentang Baku Mutu Limbah Cair Bagi Kegiatan Industri. Kementerian Lingkungan Hidup dan Kehutanan Republik Indonesia, 1995.

[2] L. Appels, J. Baeyens, J. Degrève, and R. Dewil, "Principles and Potential of The Anaerobic Digestion of Waste-Activated Sludge," Prog. Energy Combust. Sci., vol. 34, no. 6, pp. 755-781, Dec. 2008.

[3] A. Mottet, J. P. Steyer, S. Déléris, F. Vedrenne, J. Chauzy, and H. Carrère, "Kinetics of Thermophilic Batch Anaerobic Digestion of Thermal Hydrolysed Waste Activated Sludge," Biochem. Eng. J., vol. 46, no. 2, pp. 169-175, Oct. 2009.

[4] D. Bolzonella, P. Pavan, P. Battistoni, and F. Cecchi, "Mesophilic Anaerobic Digestion Of Waste Activated Sludge: Influence Of The Solid Retention Time In The Wastewater Treatment Process," Process Biochem., vol. 40, no. 3-4, pp. 1453-1460, Mar. 2005.

[5] D.-J. Kim and J. Lee, "Ultrasonic Sludge Disintegration for Enhanced Methane Production in Anaerobic Digestion: Effects of Sludge Hydrolysis Efficiency and Hydraulic Retention Time," Bioprocess Biosyst. Eng., vol. 35, no. 1-2, pp. 289-296, Jan. 2012.

[6] I. H. Franke-Whittle, A. Walter, C. Ebner, and H. Insam, "Investigation Into The Effect Of High Concentrations Of Volatile Fatty Acids In Anaerobic Digestion On Methanogenic Communities," Waste Manag. vol. 34, no. 11, pp. 2080-2089, Nov. 2014.

[7] N. Krakat, A. Westphal, S. Schmidt, and P. Scherer, "Anaerobic Digestion of Renewable Biomass : Thermophilic Temperature Governs Methanogen Population Dynamics," Appl. Environ. Microbiol., vol. 76, no. 6 , pp. 1842-1850, Mar. 2010.

[8] C. Dennehy et al., "Process Stability And Microbial Community Composition In Pig Manure And Food Waste Anaerobic Co-Digesters Operated At Low HRTs," Front. Environ. Sci. Eng., vol. 11, no. 3, Jun. 2017.

[9] K. V. Rajeshwari, M. Balakrishnan, A. Kansal, K. Lata, and V. V. N. Kishore, "State of The Art of Anaerobic Digestion Technology for Industrial Wastewater Treatment," Renew. Sustain. Energy Rev., vol. 4, no. 2, pp. 135-156, 2000.

[10] X. Li, Y. Peng, Y. He, S. Wang, S. Guo, and L. Li, "Anaerobic Stabilization Of Waste Activated Sludge At Different Temperatures And Solid Retention Times: Evaluation By Sludge Reduction, Soluble Chemical Oxygen Demand Release And Dehydration Capability," Bioresour. Technol., vol. 227, pp. 398-403, Mar. 2017.

[11] J. K. Kim, B. R. Oh, Y. N. Chun, and S. W. Kim, "Effects of Temperature and Hydraulic Retention Time on Anaerobic Digestion of Food Waste," J. Biosci. Bioeng., vol. 102, no. 4, pp. 328-332, Oct. 2006. 